\title{
THE IMPACT OF ENVIRONMENTAL PREVENTION MEASURES FOR QUALITY OF FRESH CARROTS
}

Simona PAULIKIENĖ, Institute of Energy and Biotechnology Engineering, Faculty of Agricultural Engineering, Aleksandras Stulginskis University, Studentų str. 11, LT-53361 Akademija, Kaunas region, Lithuania; simona.paulikiene@asu.It (corresponding author)

Algirdas RAILA, Institute of Energy and Biotechnology Engineering, Faculty of Agricultural Engineering, Aleksandras Stulginskis University, Studentu str. 11, LT-53361 Akademija, Kaunas region, Lithuania; algirdas.raila@asu.lt

Egidijus ZVICEVIČIUS, Institute of Energy and Biotechnology Engineering, Faculty of Agricultural Engineering, Aleksandras Stulginskis University, Studentų str. 11, LT-53361 Akademija, Kaunas region, Lithuania; egidijus.zvicevicius@asu.lt

In recent years there is an increase in consumption of food products and the supply of fresh vegetables to the consumer is getting more and more popular. However, this group of products is among the fastest perishing products. It is because of environmental and internal factors in vegetables during storage are unavoidable.

During the preparation for the market vegetables are being cleaned, washed, sanded, sorted and dried. This consumes a lot of energy and water. Different technological measures are used to reduce the consumption of natural resources during the preparation of products for the market and to slow down their quality changes. Ozone is an effective measure to slow down product bio destruction.

Ozone usage in small doses as a disinfectant is recognized as safe. Although there are a lot of publications in the usage of ozone, but its impact on vegetable qualitative indicators has not been sufficiently investigated. There is a lack of research in the analysis of the effects of ozonated water, which can be successfully used in vegetable washing technologies.

The article analyzes the effect of ozonated water treatment on fresh carrots colour and quantity of carotenoids. The obtained data showed that the use of ozonated water in concentration of $1.53 \pm 0.09 \mathrm{mg} \mathrm{L}^{-1}$ did not have an effect on the amount carotenoids accumulated in the products. Also, ozonated water did not have significant effect on the colour of products.

Keywords: Ozonized water, vegetables surface, quality, colour, carotenoids

\section{INTRODUCTION}

Over the past three decades due to the growing needs of consumers for a healthier diet and food quality requirements the fresh vegetable sector has grown significantly (Ssemanda et al. 2017, Soto-Silva et al. 2016). Fresh vegetables and fruits containing vitamins, minerals and nutrients are important component of healthy diet in children and adults (Besik and Nagurney 2017). However, fresh vegetables and fruits are classified as highly perishable products (Perez-Cueto et al. 2017) which account for the largest part of trade and consumption about 15-30 \% (Gustavsson et al. 2011).

The important part in the vegetable supply industry is the acquisition and further storage of fresh products because it is connected with the quality of end product and economical benefits (Soto-Silva et al. 2016).

Taking in the consideration all the stages of the preparation of fresh vegetable for market the washing is the first step in removing dirt and residues. Also the population of microorganisms are reduced in vegetables (Maffei et al. 2017). If it is not prepared and stored properly it can become hazardous to health due to pathogenic activities (Faour-Klingbeil et al. 2016). However with proper precautionary measures and storage it can be slowed down.

Perspective alternative for traditional disinfectants is ozone (Tzortzakis and Chrysargyris 2017). It has been recognized as safe to use in food industry by USA Generally Recognizad as Safe (GRAS). This powerful oxidant kills microorganisms and decays quickly without leaving any by-products (Sandhu et al. 2011, Li et al. 2013). Vegetables at the washing stages are effectively disinfected to destroy or reduce the number of pathogenic microorganisms without affecting the quality, safety or product (de São José et al. 2014).

Ozone is used in vegetable washing, but there is a lack of information if its use does not affect quality indicators of vegetables such as carotenoids and the colour changes. Carotenoids are pigments soluble in fats (Fernández-García et al. 2012). Carotenoids are incorporated into cellular structures in a variety of fruit and vegetable chromoplasts cells within a specific subgroup of crystalline, membranous or ring-shaped (Jeffery et al. 2012). Its physiological functions are related to its antioxidant properties and vitamin A activity (Fernández-García et al. 2012, Mutsokoti et al. 2016).

Copyright (C) 2017 The Authors. Published by Aleksandras Stulginskis University. This is an open-access article distributed under the terms of the Creative Commons Attribution License (CC-BY 4.0), which permits unrestricted use, distribution, and reproduction in any medium, provided the original author and source are credited. 
The colour of vegetable is direct reflection of the quality of product along with its recognition (Brasil and Siddiqui 2018). The measuring of colour also show what changes occur in food products (Kaur and Sharma 2013). Consumers are likely to notice the changes of colour, but the natural vegetable colour is unstable and easily altered during processing (Kowalski et al. 2013). The purpose of this study was to examine the effect of fresh vegetable treatment with ozone to their colour and the amount of carotenoids accumulated.

\section{MATERIALS AND METHODS}

\section{Materials}

Carrots was chosen for testing as they have a thin peel so their qualitative indicators can be damaged by processing with ozone. For the study are used medium size and similar form (weight $-96.28 \pm 2.04 \mathrm{~g}$ and length $190.0 \pm 10 \mathrm{~mm}$ ) late breeds carrots grown in middle of Lithuania. Carrots (Daucus carota L.) are the one of the most important root vegetables that contains a lot of biologically active compounds such as carotenoids and dietary fibers that contain many other functional components with significant health-promoting characteristics (Hashimoto and Nagayama 2004).

\section{Ozonation process}

Sample preparation. 6 samples of 7 carrots (hereinafter referred to as "samples") are numbered (repeated 6 times). The specimens are classified as follows:

- Samples 1 (B1) - rinsed with ozonated water for $5 \mathrm{~min}$

- Samples 2 (B2) - rinsed with ozonated water for $10 \mathrm{~min}$;

- Samples 3 (B3) - rinsed with ozonated water for $15 \mathrm{~min}$;

- Samples 4 (B4) - rinsed with ozonated water for $20 \mathrm{~min}$;

- Samples 5 (B5) - samples rinsed with tap water;

- Samples 6 (B6) - control - untreated.

Rinsing of samples with ozonated water. The ozonated water was prepared by ozone water generator OZ-AW-15 (power $2 \mathrm{~kW}$, flow of treated water $-5 \mathrm{~m}^{3} \mathrm{~h}^{-1}$, ozone generation rate $-15 \mathrm{~g} \mathrm{~h}^{-1}$ ). Ozone is fed through an ejector to a container with water (water content 1.51 , ozone concentration in water $-1.5 \pm \mathrm{mg} \mathrm{L}^{-1}$ ). To determine the concentration of ozone in water was used Chemetrics CHEMets Test Kits for ozone.

One sample from every set is taken and set aside for further qualitative measurements.

\section{Storage}

The remaining six samples are subdivided into two parts. Samples are pooled in threes and put into bags with holes for storage. The first samples are put into incubator, which maintains recommended temperature for storage for most produce $\left(3.0 \pm 0.15^{\circ} \mathrm{C}\right.$, relative humidity $\left.-86.5 \pm 2.0 \%\right)$. Second batch of samples are placed at $16.0 \pm 1.0^{\circ} \mathrm{C}$ temperature (relative humidity $-41.6 \pm 2.3 \%$ ). Samples were taken from each of the samples stored at different temperatures after 7 days (on day 8), 19 days (on day 20) and 35 days (on day 36) to determine qualitative parameters.

\section{Colour coordinates}

Preparing the device for analysis. Ready-to-use Spectrometer "ColorFlex" is calibrated by using standard white and black plates. Data is recorded by HunterLabTM software. The luminous flare mode measures the parameters: L*, $\mathrm{a}^{*}$ and $\mathrm{b}^{*}$ (corresponding to brightness, red and yellow coordinates according to the CIE $\mathrm{L}^{*} \mathrm{a}^{*} \mathrm{~b}^{*}$ scale) and the color purity $\left(C^{*}=\left(a^{*} 2+b^{* 2}\right) 1 / 2\right)$ and the color tone $\left(h^{\circ}=\arctan \left(b^{*} / a^{*}\right)\right)$ is calculated. The values of $L^{*}, C^{*}$ and $b^{*}$ are measured in USA National Bureau of Standards unit (NBS), color tone $h^{\circ}$ is measured in degrees from $0^{\circ}$ to $360^{\circ}$. NBS unit - a unit of the US National Standards Bureau that meets one color separation threshold, i.e. the smallest difference in color that can be captured by the trained human eye (AOAC 1990).

Preparation of the sample for analysis. The carrots are cut into three parts and the sample is measured in three replicates.

Sample scan. The prepared sample is placed on the device and then covered with a light-proof cap. The cap reduces the effect of light on the actual color. Measurement is performed. The sample color is scanned three times, each time the glass is changed, i.e. the sample is moved.

\section{Determination of carotenoids}

The set up of graduation diagram. Transfer 5; 10;20;30; 40 and $50 \mathrm{ml}$ of standard potassium bichromate solution $\left(0.72 \mathrm{~g} \mathrm{~L}^{1}\right)$ into $50 \mathrm{ml}$ measuring flask and make up to the mark with distillated water. Distilated water is pourn into comparative cuvette. The optical density of the prepared solutions is measured with The Perkin Elmer UV/VIS Spectrometer Lambda 25 (accuracy \pm 0.001 ) by using $10 \mathrm{~mm}$ wide cuvette and blue light filter. Measure with glass cuvette (400 ml).

According to the received data, the graph is plotted: in the $\mathrm{x}$-axis, we set the standard ml solution, and the y-axis is the optical density.

Analysis. 1-5 g of minced sample is put into $100 \mathrm{ml}$ cogical flask (sanded). Add $5 \mathrm{~g}$ of anhydrous sodium sulfate, $5 \mathrm{~g}$ of $10 \%$ alumina and $0.5 \mathrm{~g}$ of ca-lcium oxide, and $50 \mathrm{ml}$ of benzene or acetone. The flask is tightly corked and kept in the dark for $18-20 \mathrm{~h}$. The next day the optical density of the solution is measured. The quantity of carotene is calculated according to the formula (Gražulevičienè et al.1999): 


$$
X=\frac{a \cdot 0,00416 \cdot 100}{m}, \mathrm{mg} \%
$$

where $\quad a$-found in graduation diagrama, $\mathrm{ml}$;

$m$ - the amount of sample taken for analysis, $\mathrm{g}$;

0,00416 - carotene quantity in one $\mathrm{ml}$ of standart solution, $\mathrm{mg}$.

\section{Statistical analysis}

The study data is processed by the Microsoft Excel program using the Student t-test and the significance level of the received data is 0.05 .

\section{RESULTS AND DISCUSSION}

It is very important to prepare and store carrots corectly during the preparation for commercial usage in order to keep its quality and attractivness for long periods of time. Therefore ozonated water is used as a preventetive measure during rinsing to minimize microorganismes. Smilanick (2003) and Suslow (2004) states that 0.5 to $2 \mathrm{mg} \mathrm{L}^{-1}$ ozone concentrations in water are required to destroy microorganisms. In the laboratory carrots were rinsing with ozonated water which had ozone concentration of $1.53 \pm 0.09 \mathrm{mg} \mathrm{L}^{-1}$.

It was chosen to carry out tests on carrot color and accumulated carotenoids to determine the quality of treated samples. The white/black ( $\mathrm{L}^{*}$ ) ratio were found to be on average between 45.76 and $51.98 \mathrm{NBS}$ units during the storage period at both temperatures with treated (rinsed with ozonized water and tap water) and untreated (control) samples. Changes in color of the surface of the treated samples and untreated samples, expressed in terms of the color purity $\mathrm{C}^{*}$ and the color tone $\mathrm{h}^{\circ}$, are shown in Tables 1 and 2. It was found that among the samples that were rinsed with ozonated water in different time regimes (day 36), i.e. 5, 10, 15 and 20 min. a significant difference in mean was not observed (p $<0.05)$. In a further discussion of the study, the comparison of mean of all samples rinsed with ozonated water with different time regimes will be carried out.

Table 1 shows the variation of samples, which were held in $3.0 \pm 0.15^{\circ} \mathrm{C}$ and $16.0 \pm 1.0^{\circ} \mathrm{C}$ temperatures, color tone on different days. On average, the color tone value at $3.0 \pm 0.15^{\circ} \mathrm{C} \mathrm{(36} \mathrm{day)} \mathrm{for} \mathrm{samples} \mathrm{rinsed} \mathrm{with} \mathrm{ozonated} \mathrm{water}$ (B1.1-B4.1) was $47.36 \pm 1.01^{\circ}$, for sample rinsed with tap water (B5.1) $-46.92 \pm 0.79^{\circ}$ and control (B6.1) $-47.78 \pm$ $0.81^{\circ}$. At higher temperature, i.e. at $16.0 \pm 1.0^{\circ} \mathrm{C}$, the mean for the sample rinsed with ozonated water (B1.2 - B4.2) was $48.57 \pm 1.35^{\circ}$, for samples rinsed with tap water (B5.2) was $49.00 \pm 0.72^{\circ}$ and control (B6. 2) $-49.75 \pm 1.24^{\circ}$.

Based on the results and comparing of the samples treated with ozonated water with control samples $(3.0 \pm$ $\left.0.15^{\circ} \mathrm{C}\right)$, the color tone value decreased slightly $(\mathrm{p}<0.05)-0.86 \%$. And the difference in the color of the tonnage treated with tap water alone was $1.8 \%$ compared to the control samples. Table 1 shows the mean of data and the difference in letters is showing a significant difference of $5 \%(\mathrm{p}<0.05)$ using Student's t-test between the samples. It is showed that there were no significant differences in the mean between samples treated with ozonated water and treated with plain water or control samples $(\mathrm{p}<0.05)$.

Table 1. Variation in carrot color tone $\left(\mathrm{h}^{\circ},{ }^{\circ}\right)$ during storage. Variation in the letters between samples indicates significance difference at $5 \%$ level $(\mathrm{p}<0.05)$ utilizing Student's t-test.

\begin{tabular}{|c|c|c|c|c|}
\hline \multirow{2}{*}{ Processing methods } & \multicolumn{4}{|c|}{ Carrot color tune } \\
\hline & Day 1 & Day 8 & Day 20 & Day 36 \\
\hline \multicolumn{5}{|l|}{$\begin{aligned} & \text { Temperature } 3.0 \pm 0.15^{\circ} \mathrm{C} \text {, relative humidity } \\
&-86.5 \pm 2.0 \% \\
&\end{aligned}$} \\
\hline B1.1 - Rinsed with ozonated water for $5 \mathrm{~min}$ & $48.96 \pm 0.99 \mathrm{a}$ & $47.72 \pm 1.14 \mathrm{a}$ & $47.81 \pm 0.70 \mathrm{ab}$ & $47.45 \pm 1.42 \mathrm{a}$ \\
\hline B2.1 - Rinsed with ozonated water for $10 \mathrm{~min}$ & $47.44 \pm 1.04 \mathrm{~b}$ & $49.41 \pm 1.20 \mathrm{~b}$ & $47.63 \pm 0.36 \mathrm{ab}$ & $47.32 \pm 0.63 \mathrm{a}$ \\
\hline B3.1 - Rinsed with ozonated water for $15 \mathrm{~min}$ & $48.60 \pm 0.79 \mathrm{a} \mathrm{b} \mathrm{c}$ & $48.30 \pm 0.73 \mathrm{a} \mathrm{b}$ & $46.92 \pm 0.91 \mathrm{bc}$ & $47.39 \pm 1.26 \mathrm{a}$ \\
\hline B4.1 - Rinsed with ozonated water for $20 \mathrm{~min}$ & $47.55 \pm 0.82 \mathrm{~b}$ & $48.21 \pm 1.11 \mathrm{a} \mathrm{b}$ & $48.41 \pm 1.07 \mathrm{a} \mathrm{b}$ & $47.29 \pm 0.72 \mathrm{a}$ \\
\hline B5.1 - Rinsed with tap water & $47.29 \pm 1.06 \mathrm{~b} \mathrm{c}$ & $47.61 \pm 0.65 \mathrm{a}$ & $47.45 \pm 0.45 \mathrm{abc}$ & $46.92 \pm 0.79 \mathrm{a}$ \\
\hline B6.1 - Control - untreated & $47.46 \pm 1.47 \mathrm{~b} \mathrm{c}$ & $49.12 \pm 1.43 \mathrm{~b}$ & $49.32 \pm 0.69 \mathrm{~d}$ & $47.78 \pm 0.81 \mathrm{a}$ \\
\hline $\mathrm{n}=216$ & $\operatorname{LSD}_{0,05}(\mathrm{D} 1.1)=1.18$ & $\mathrm{LSD}_{0,05}(\mathrm{D} 8.1)=1.21$ & $\begin{array}{c}\mathrm{LSD}_{0,05}(\mathrm{D} 20.1)= \\
0.83\end{array}$ & $\begin{array}{c}\mathrm{LSD}_{0,05}(\mathrm{D} 36.1)= \\
1.10\end{array}$ \\
\hline \multicolumn{5}{|l|}{$\begin{array}{c}\text { Temperature } 16.0 \pm 1.0^{\circ} \mathrm{C} \text {, relative humidity } \\
-41.6 \pm 2.3 \% \\
\end{array}$} \\
\hline B1.2 - Rinsed with ozonated water for $5 \mathrm{~min}$ & $48.96 \pm 0.99 \mathrm{a} \mathrm{c}$ & $47.93 \pm 0.75 \mathrm{a} \mathrm{b}$ & $49.43 \pm 0.91 \mathrm{a}$ & $48.96 \pm 0.82 \mathrm{ab}$ \\
\hline B2.2 - Rinsed with ozonated water for $10 \mathrm{~min}$ & $47.44 \pm 1.04 \mathrm{~b}$ & $47.58 \pm 0.93 \mathrm{a}$ & $47.48 \pm 0.73 \mathrm{~b} \mathrm{c}$ & $48.03 \pm 1.24 \mathrm{a} \mathrm{b}$ \\
\hline B3.2 - Rinsed with ozonated water for $15 \mathrm{~min}$ & $48.60 \pm 0.79 \mathrm{abc}$ & $47.78 \pm 1.21 \mathrm{a}$ & $48.45 \pm 0.56 \mathrm{c}$ & $48.32 \pm 1.65 \mathrm{ab}$ \\
\hline B4.2 - Rinsed with ozonated water for $20 \mathrm{~min}$ & $47.55 \pm 0.82 \mathrm{~b}$ & $47.19 \pm 1.01 \mathrm{a} \mathrm{b}$ & $49.15 \pm 0.58 \mathrm{a} \mathrm{c}$ & $48.98 \pm 1.69 \mathrm{a} \mathrm{b}$ \\
\hline B5.2 - Rinsed with tap water & $47.29 \pm 1.06 \mathrm{~b} \mathrm{c}$ & $48.78 \pm 1.21 \mathrm{a}$ & $47.83 \pm 0.43 \mathrm{bc}$ & $49.00 \pm 0.72 \mathrm{a} \mathrm{b}$ \\
\hline B6.2-Control - untreated & $47.46 \pm 1.47 \mathrm{~b} \mathrm{c}$ & $47.68 \pm 1.69 \mathrm{a} \mathrm{b}$ & $49.02 \pm 0.74 \mathrm{a} \mathrm{c}$ & $49.75 \pm 1.24 \mathrm{a}$ \\
\hline 216 & $\operatorname{LSD}_{0,05}(\mathrm{D} 1.2)=1.18$ & $\mathrm{LSD}_{0,05}(\mathrm{D} 8.2$ & $\begin{array}{c}\mathrm{LSD}_{0,05}(\mathrm{D} 20.2)= \\
0.76\end{array}$ & $\begin{array}{c}\mathrm{LSD}_{0,05}(\mathrm{D} 36.2)= \\
1.42\end{array}$ \\
\hline
\end{tabular}

The values of the purity of treated and control samples are given in Table 2 . The color purity at $3.0 \pm 0.15^{\circ} \mathrm{C}(36$ days) on avarage of the samples rinsed with ozonated water (B1.1 - B4.1) was 54.56 \pm 2.70 NBS units, the sample rinsed with tap water (B5.1) was 57.49 \pm 4.34 NBS units and Controls (B6.1) - 52.86 \pm 2.45 NBS units. At a temperature of 
$16.0 \pm 1.0^{\circ} \mathrm{C}$, the color of the samples rinsed with ozonized water had a purity mean of $55.75 \pm 4.20 \mathrm{NBS}$ units, sample rinsed with tap water had the mean of $55.53 \pm 3.86 \mathrm{NBS}$ units and a control unit of $50.61 \pm 3.98$ NBS units.

Thus, the change in the colour purity at $3.0 \pm 0.15^{\circ} \mathrm{C}$, of samples treated with ozonated water was $3.01 \%$ higher than control samples, but $5.20 \%$ lower than that of rinsed with tap water. The purity of the colour for samples stored at $16.0 \pm 1.0^{\circ} \mathrm{C}$ and rinsed with ozonated water was $9.23 \%$ higher than that of the control and $0.39 \%$ higher than that of tap water. In the evaluation of the carrot color purity values given in Table 2, we can see that there was no significant difference between the samples treated with ozonated water and treated with tap water or bigger significant differences in control samples $(\mathrm{p}<0.05)$. It can be stated that the carrot color changes was not affected by ozonated water.

Table 2. The changes in carrot color purity, (C*, NBS units) during storage. Variation in the letters between samples indicates significance difference at $5 \%$ level $(\mathrm{p}<0.05)$ utilizing Student's t-test.

\begin{tabular}{|c|c|c|c|c|}
\hline \multirow{2}{*}{ Processing methods } & \multicolumn{4}{|c|}{ Carrot color purity } \\
\hline & Day 1 & Day 8 & Day 20 & Day 36 \\
\hline \multicolumn{5}{|l|}{$\begin{aligned} & \text { Temperature } 3.0 \pm 0.15^{\circ} \mathrm{C} \text {, relative humidity } \\
&-86.5 \pm 2.0 \% \\
&\end{aligned}$} \\
\hline B1.1 - Rinsed with ozonated water for $5 \mathrm{~min}$ & $66.06 \pm 5.75 \mathrm{a} \mathrm{b}$ & $60.57 \pm 4.83 \mathrm{a}$ & $56.12 \pm 4.10 \mathrm{abc}$ & $54.12 \pm 3.00 \mathrm{a} \mathrm{b} \mathrm{c}$ \\
\hline B2.1 - Rinsed with ozonated water for $10 \mathrm{~min}$ & $61.62 \pm 3.84 \mathrm{ab}$ & $61.70 \pm 6.33 \mathrm{a}$ & $52.90 \pm 1.92 \mathrm{ab}$ & $53.21 \pm 2.29 \mathrm{ab}$ \\
\hline B3.1 - Rinsed with ozonated water for $15 \mathrm{~min}$ & $63.77 \pm 6.85 \mathrm{~b} \mathrm{c}$ & $61.65 \pm 5.06 \mathrm{a}$ & $56.56 \pm 3.11 \mathrm{ab}$ & $57.18 \pm 2.96 \mathrm{a} \mathrm{c}$ \\
\hline B4.1 - Rinsed with ozonated water for $20 \mathrm{~min}$ & $55.40 \pm 2.55 \mathrm{~b}$ & $56.40 \pm 3.45 \mathrm{a}$ & $53.47 \pm 4.35 \mathrm{ab}$ & $53.47 \pm 2.56 \mathrm{ab}$ \\
\hline B5.1 - Rinsed with tap water & $58.81 \pm 6.90 \mathrm{~b} \mathrm{c}$ & $60.11 \pm 5.80 \mathrm{a}$ & $57.29 \pm 4.10 \mathrm{a} \mathrm{c}$ & $57.49 \pm 4.34 \mathrm{a} \mathrm{c}$ \\
\hline B6.1 - Control - untreated & $55.43 \pm 6.03 \mathrm{~b}$ & $60.76 \pm 7.54 \mathrm{a}$ & $51.37 \pm 3.91 \mathrm{abc}$ & $50.61 \pm 2.45 \mathrm{a} \mathrm{b}$ \\
\hline $\mathrm{n}=216$ & $\mathrm{LSD}_{0,05}(\mathrm{D} 1.1)=6.24$ & $\mathrm{LSD}_{0,05}(\mathrm{D} 1.1)=6.35$ & $\mathrm{LSD}_{0,05}(\mathrm{D} 8.1)=4.13$ & $\begin{array}{c}\mathrm{LSD}_{0,05}(\mathrm{D} 20.1)= \\
3.67\end{array}$ \\
\hline \multicolumn{5}{|l|}{$\begin{array}{r}\text { Temperature } 16.0 \pm 1.0^{\circ} \mathrm{C} \text {, relative humidity } \\
-41.6 \pm 2.3 \%\end{array}$} \\
\hline B1.2 - Rinsed with ozonated water for $5 \mathrm{~min}$ & $66.06 \pm 5.75 \mathrm{a} \mathrm{b}$ & $62.17 \pm 8.13 \mathrm{abc}$ & $57.06 \pm 2.78 \mathrm{abc}$ & $54.86 \pm 3.70 \mathrm{abc}$ \\
\hline B2.2 - Rinsed with ozonated water for $10 \mathrm{~min}$ & $61.62 \pm 3.84 \mathrm{a} \mathrm{b}$ & $62.32 \pm 4.20 \mathrm{abc}$ & $56.81 \pm 2.28 \mathrm{a} \mathrm{b}$ & $50.37 \pm 3.33 \mathrm{ab}$ \\
\hline B3.2 - Rinsed with ozonated water for $15 \mathrm{~min}$ & $63.77 \pm 6.85 \mathrm{~b} \mathrm{c}$ & $58.11 \pm 8.92 \mathrm{ab}$ & $57.07 \pm 4.44 \mathrm{abc}$ & $58.41 \pm 5.74 \mathrm{a} \mathrm{c}$ \\
\hline B4.2 - Rinsed with ozonated water for $20 \mathrm{~min}$ & $55.40 \pm 2.55 \mathrm{~b}$ & $62.46 \pm 4.05 \mathrm{abc}$ & $57.93 \pm 2.59 \mathrm{abc}$ & $57.78 \pm 4.04 \mathrm{ac}$ \\
\hline B5.2 - Rinsed with tap water & $58.81 \pm 6.90 \mathrm{bc}$ & $57.14 \pm 3.09 \mathrm{a} \mathrm{b}$ & $53.52 \pm 2.78 \mathrm{~b}$ & $55.53 \pm 3.86 \mathrm{a} \mathrm{c}$ \\
\hline B6.2-Control - untreated & $55.43 \pm 6.03 \mathrm{~b}$ & $64.73 \pm 2.87 \mathrm{a} \mathrm{c}$ & $48.58 \pm 3.00 \mathrm{~d}$ & $50.61 \pm 3.98 \mathrm{ab}$ \\
\hline $\mathrm{n}=216$ & $\mathrm{LSD}_{0,05}(\mathrm{D} 1.2)=6.24$ & $\mathrm{LSD}_{0,05}(\mathrm{D} 1.2)=6.45$ & $\mathrm{LSD}_{0,05}(\mathrm{D} 8.2)=3.44$ & $\begin{array}{c}\mathrm{LSD}_{0,05}(\mathrm{D} 20.2)= \\
4.70\end{array}$ \\
\hline
\end{tabular}

When assessing the color purity of treated and untreated carrots, it can be noted that when carrots are stored for a long period of time, the color purity gradually decreases. The purity of carrots, stored at $3.0 \pm 0.15^{\circ} \mathrm{C}$ for 36 days, decreased by about $9.07 \%$. And the carrots, which were stored at $16.0 \pm 1.0^{\circ} \mathrm{C}$ for 36 days, reduced the purity of the color by about $8.7 \%$. Although the changes in the color values between both storage temperatures of all samples differs slightly, the change in higher temperature is lower than the changes in lower temperature. This may be associated with higher losses of moisture, which results in an increase in the concentration of carotenoids in samples. Kaur and Sharma (2013) and Sowbhagya and Chitra (2010) confirms the correlation between the amount of retinoids and the intensity of color, claiming that the carrot's color depends on carotenoids in it. As we shall see later, the amount of carotenoids in the second half of the maintenance period is greatly increased.

Table 3 shows the amount of carotenoids accumulated in treated and untreated carrots and its variation during storage periods at different temperatures. Initial (day 1) quantity of carotenoids in carrots treated with ozone (B1 - B4) averaged $27.31 \pm 2.70 \mathrm{mg} \%$, treated with tap water (B5) $-28.37 \pm 0.74 \mathrm{mg} \%$ and control (B6) $-27.77 \pm 3.51 \mathrm{mg} \%$.

Table 3. Carotenoid content $(\mathrm{mg} \%)$ accumulated in carrots during storage. Variation in the letters between samples indicates significance difference at $5 \%$ level $(\mathrm{p}<0.05)$ utilizing Student's t-test.

\begin{tabular}{|c|c|c|c|c|}
\hline \multirow{2}{*}{ Processing methods } & \multicolumn{4}{|c|}{ Carotenoid content } \\
\hline & Day 1 & Day 8 & Day 20 & Day 36 \\
\hline $\begin{aligned} & \text { Temperature } 3.0 \pm 0.15^{\circ} \mathrm{C} \text {, relative humidity } \\
&-86.5 \pm 2.0 \% \\
&\end{aligned}$ & & & & \\
\hline B1.1 - Rinsed with ozonated water for $5 \mathrm{~min}$ & $26.50 \pm 2.37 \mathrm{a} \mathrm{b}$ & $26.19 \pm 1.04 \mathrm{abc}$ & $30.75 \pm 1.59 \mathrm{ab}$ & $32.13 \pm 2.11 \mathrm{a}$ \\
\hline B2.1 - Rinsed with ozonated water for $10 \mathrm{~min}$ & $29.23 \pm 4.85 \mathrm{a} \mathrm{b}$ & $26.10 \pm 1.67 \mathrm{a} \mathrm{b}$ & $28.54 \pm 3.33 \mathrm{ab}$ & $29.09 \pm 2.84 \mathrm{~b}$ \\
\hline B3.1 - Rinsed with ozonated water for $15 \mathrm{~min}$ & $27.88 \pm 1.04 \mathrm{ab}$ & $27.64 \pm 0.38 \mathrm{a} \mathrm{c}$ & $31.13 \pm 2.49 \mathrm{ab}$ & $31.94 \pm 0.57 \mathrm{a}$ \\
\hline B4.1 - Rinsed with ozonated water for $20 \mathrm{~min}$ & $25.62 \pm 2.54 \mathrm{a}$ & $26.87 \pm 0.64 \mathrm{abc}$ & $30.20 \pm 2.88 \mathrm{a} \mathrm{b}$ & $31.90 \pm 0.69 \mathrm{a}$ \\
\hline B5.1 - Rinsed with tap water & $28.37 \pm 0.74 \mathrm{ab}$ & $26.00 \pm 1.97 \mathrm{a} \mathrm{b}$ & $30.14 \pm 2.07 \mathrm{ab}$ & $30.98 \pm 0.90 \mathrm{a} \mathrm{b}$ \\
\hline B6.1 - Control - untreated & $27.77 \pm 3.51 \mathrm{ab}$ & $26.96 \pm 0.35 \mathrm{abc}$ & $31.57 \pm 1.87 \mathrm{a}$ & $31.85 \pm 2.14 \mathrm{a}$ \\
\hline $\mathrm{n}=81$ & $\mathrm{LSD}_{0,05}(\mathrm{D} 1.1)=3.55$ & $\mathrm{LSD}_{0,05}(\mathrm{D} 1.1)=1.46$ & $\mathrm{LSD}_{0,05}(\mathrm{D} 8.1)=3.02$ & $\begin{array}{c}\operatorname{LSD}_{0,05}(\mathrm{D} 20.1)= \\
2.18\end{array}$ \\
\hline $\begin{array}{r}\text { Temperature } 16.0 \pm 1.0^{\circ} \mathrm{C}, \text { relative humidity } \\
-41.6 \pm 2.3 \%\end{array}$ & & & & \\
\hline B1.2 - Rinsed with ozonated water for $5 \mathrm{~min}$ & $26.50 \pm 2.37 \mathrm{a} \mathrm{b}$ & $25.24 \pm 1.54 \mathrm{a}$ & $31.84 \pm 2.54 \mathrm{abc}$ & $38.06 \pm 0.72 \mathrm{abc}$ \\
\hline B2.2 - Rinsed with ozonated water for $10 \mathrm{~min}$ & $29.23 \pm 4.85 \mathrm{a} \mathrm{b}$ & $26.04 \pm 2.34 \mathrm{~b}$ & $33.24 \pm 1.04 \mathrm{ab}$ & $38.55 \pm 0.83 \mathrm{ab}$ \\
\hline B3.2 - Rinsed with ozonated water for $15 \mathrm{~min}$ & $27.88 \pm 1.04 \mathrm{ab}$ & $27.73 \pm 3.18 \mathrm{abc}$ & $34.57 \pm 0.91 \mathrm{~b}$ & $39.22 \pm 0.90 \mathrm{abc}$ \\
\hline B4.2 - Rinsed with ozonated water for $20 \mathrm{~min}$ & $25.62 \pm 2.54 \mathrm{a}$ & $25.28 \pm 1.42 \mathrm{a} \mathrm{b}$ & $33.12 \pm 2.61 \mathrm{ab}$ & $37.82 \pm 0.23 \mathrm{ab}$ \\
\hline B5.2 - Rinsed with tap water & $28.37 \pm 0.74 \mathrm{a} \mathrm{b}$ & $25.93 \pm 1.37 \mathrm{abc}$ & $32.90 \pm 0.97 \mathrm{a} \mathrm{bc}$ & $39.45 \pm 1.14 \mathrm{bc}$ \\
\hline B6.2-Control - untreated & $27.77 \pm 3.51 \mathrm{ab}$ & $26.65 \pm 0.69 \mathrm{abc}$ & $30.69 \pm 2.64 \mathrm{a} \mathrm{c}$ & $34.91 \pm 2.04 \mathrm{~d}$ \\
\hline $\mathrm{n}=81$ & $\mathrm{LSD}_{0,05}(\mathrm{D} 1.2)=3.55$ & $\mathrm{LSD}_{0,05}(\mathrm{D} 1.2)=2.38$ & $\mathrm{LSD}_{0,05}(\mathrm{D} 8.2)=2.42$ & $\begin{array}{c}\mathrm{LSD}_{0,05}(\mathrm{D} 20.2)= \\
1.38\end{array}$ \\
\hline
\end{tabular}


The carotenoid quantity in the samples stored for 36 days at $3.0 \pm 0.15^{\circ} \mathrm{C}$ temperature slightly increased. In carrots rinsed with ozonated water carotenoids (B1.1 - B4.1) increased to $12.66 \%(31.27 \pm 1.55 \mathrm{mg} \%)$. Carotenoid quantity in carrots rinsed with tap water (B5.1) increased to $8.41 \%$ (30.98 $\pm 0.90 \mathrm{mg} \%$ ) and control (B6.1) to $12.81 \%$ (31.85 $\pm 2.14 \mathrm{mg} \%$ ), respectively.

The effect of storage duration at $16.0 \pm 1.0^{\circ} \mathrm{C}$ was statistically significant $(\mathrm{p}<0.05)$, but the carotenoid content rose during storage. From the study data, we can see that the amount of carotenoids accumulated at 36 day significantly increased. After the storage period, carotenoids in the samples rinsed with ozonated water (B1.2 - B4.2) increased by $28.91 \%(38.41 \pm 0.67 \mathrm{mg} \%)$, in the samples rinsed with tap water (B5.2) increased by $28.09 \%(39.45 \pm 1.14 \%)$ and in the control samples (B6.2) increased by $20.46 \%(34.91 \pm 2.04 \%)$. This can be explained by the loss of moisture, as humidity is more strongly evaporated at higher temperature during storage. Carotenoids in the product remain the same, but there is less moisture in sample even though the amount of sample taken does not change.

It can also be observed that the carotenoid content of the control samples is lower at $16.0 \pm 1.0^{\circ} \mathrm{C}$ at 20 day and 36 days, it is because that the control samples are non-rinsed and covered with dirt. This affected the moisture evaporation intensity.

When evaluating the data in Table 3, we can see that there were no significant differences between treated and untreated samples $(\mathrm{p}<0.05)$.

It was determined that ozonated water used in rinsing at the concentration of $1.53 \pm 0.09 \mathrm{mg} \mathrm{L}^{-1}$ during the commercial preparation did not affect the accumulated carotenoids content. Since ozone acts only on the surface of the product as a disinfectant, and the main carotenoid content is in the inner carrot layers. According to Chauhan et. al. (2011) carotenoids quickly react with molecular oxygen because they automatically oxidize. But it also confirms that ozones oxidative effect on food is a surface phenomenon (Chauhan et al. 2011, Rice et al. 1982).

\section{CONCLUSIONS}

1. It was determined that ozonated water at a concentration of $1.53 \pm 0.09 \mathrm{mg} \mathrm{L}^{-1}$ did not have significant effect on changes in carrots color.

2. No significant effect on fresh carrots was observed between the processing times $(5,10,15,20$ min) with ozonated water.

1. It was estimated that ozonated water that was used to rinse carrots did not affect the carotenoids accumulated in carrots. After storing carrots for 36 days at $3.0 \pm 0.15^{\circ} \mathrm{C}$ temperature carotenoids increased by $12.66 \%$. Respectively, carotenoids in carrots rinsed with tap water increased by $8.41 \%$ and by $12.81 \%$ in the control group. When storing carrots for 36 days in higher temperature $\left(16.0 \pm 1.0^{\circ} \mathrm{C}\right)$ the total carotenoid amount in carrots rinsed with ozonated water increased by $28.91 \%$, in carrots rinsed with tap water increased by $28.09 \%$, and in the control group by 20.46 $\%$. Increases in carotenoids can be explained by higher moisture losses.

\section{REFERENCES}

1. AOAC. 1990. Official Methods of Analysis. Arlington, Virginia: Association of Official Analytical Chemists.

2. Besik, D., Nagurney, A. 2017. Quality in competitive fresh produce supply chains with application to farmers markets. SocioEconomic Planning Sciences, pp.62-76. https://doi.org/10.1016/j.seps.2017.03.001

3. Brasil, I.M., Siddiqui, M.W. 2018. Chapter 1 - Postharvest Quality of Fruits and Vegetables: An Overview. Siddiqui, M.W., ed. 2018. Preharvest Modulation of Postharvest Fruit and Vegetable Quality. Academic Press., pp.1-40.

4. Chauhan, O.P., Raju, P.S., Ravi, N., Singh, A., Bawa, A.S. 2011. Effectiveness of ozone in combination with controlled atmosphere on quality characteristics including lignification of carrot sticks. Journal of Food Engineering, Vol. 102, Iss. 1, pp.43-48. https://doi.org/10.1016/j.seps.2017.03.001

5. Faour-Klingbeil, D., Todd, E.C.D., Kuri, V. 2016. Microbiological quality of ready-to-eat fresh vegetables and their link to food safety environment and handling practices in restaurants. LWT - Food Science and Technology, Vol. 74 (Supplement C), pp. 224-233. https://doi.org/10.1016/j.lwt.2016.07.051

6. Fernández-García, E., Carvajal-Lérida, I., Jarén-Galán, M., Garrido-Fernández, J., Pérez-Gálvez, A., Hornero-Méndez, D., 2012. Carotenoids bioavailability from foods: From plant pigments to efficient biological activities. Food Research International, Vol. 46, Iss. 2, pp. 438-450. https://doi.org/10.1016/j.foodres.2011.06.007

7. Gražulevičienė V., Rutkauskienė G., Vedegytė J. 1999. Metodiniai patarimai organinès chemijos laboratoriniams darbams. Kaunas - Akademija: LŽŪU Leidybinis centras, pp. 44.

8. Gustavsson, J., Cederberg, C., Sonesson, U., Otterdijk, R.v., Meybeck, A. 2011. Global food losses and food waste. Rome: Food and Agriculture Organization Of The United Nations.

9. Hashimoto, T., Nagayama, T. 2004. Chemical composition of ready-to-eat fresh carrot. Journal of the Food Hygienic Society of Japan, Vol. 39, pp. 324-328. https://doi.org/10.3358/shokueishi.39.5_324

10. Jeffery, J., Holzenburg, A., King, S. 2012. Physical barriers to carotenoid bioaccessibility. Ultrastructure survey of chromoplast and cell wall morphology in nine carotenoid-containing fruits and vegetables. Journal of the Science of Food and Agriculture, Vol. 92, Iss. 13, pp. 2594-2602. https://doi.org/10.1002/jsfa.5767

11. Kaur, M., Sharma, H.K. 2013. Effect of enzymatic treatment on carrot cell wall for increased juice yield and effect on physicochemical parameters. African Journal of Plant Science, Vol. 7, Iss. 6, pp. 234-243. https://doi.org/10.5897/AJPS12.166

12. Kowalski, S.J., Szadzińska, J., Łechtańska, J. 2013. Non-stationary drying of carrot: Effect on product quality. Journal of Food Engineering, Vol. 118, Iss. 4, pp. 393-399. https://doi.org/10.1016/j.jfoodeng.2013.04.028 
13. Li, M., Peng, J., Zhu, K., Guo, X., Zhang, M., Peng, W., Zhou, H. 2013. Delineating the microbial and physical-chemical changes during storage of ozone treated wheat flour. Innovative Food Science \& Emerging Technologies, Vol. 20, pp. $223-229$. https://doi.org/10.1016/j.ifset.2013.06.004

14. Maffei, D.F., Sant'Ana, A.S., Franco, B.D.G.M., Schaffner, D.W. 2017. Quantitative assessment of the impact of crosscontamination during the washing step of ready-to-eat leafy greens on the risk of illness caused by Salmonella. Food Research International, Vol. 92 (Supplement C), pp. 106-112. https://doi.org/10.1016/j.foodres.2016.12.014

15. Mutsokoti, L., Panozzo, A., Van Loey, A., Hendrickx, M. 2016. Carotenoid transfer to oil during thermal processing of low fat carrot and tomato particle based suspensions. Food Research International, Vol. 86 (Supplement C), pp. 64-73. https://doi.org/10.1016/j.foodres.2016.05.019

16. Perez-Cueto, F.J.A., Dos Santos, Q., Nielsen, B., Dinnella, C., Monteleone, E., Giboreau, A., Saulais, L., Depezay, L., Hartwell, H., Appleton, K. 2017. Danish adolescents like their vegetables fresh rather than frozen or canned. International Journal of Gastronomy and Food Science, Vol. 9 (Supplement C), pp. 29-33. https://doi.org/10.1016/j.ijgfs.2017.05.003

17. Rice, R.G., Farquhar, J.W., Bollyky, L.J. 1982. Review of the applications of ozone for increasing storage times of perishable foods. Ozone Science Engineering, Vol. 4, pp. 147-163.

18. Sandhu, H.P.S., Manthey, F.A., Simsek, S. 2011. Quality of bread made from ozonated wheat (Triticum aestivum L.) flour. Journal of the Science of Food and Agriculture, Vol. 91, Iss. 9, pp. 1576-1584. https://doi.org/10.1002/jsfa.4350

19. de São José,J.F.B., Andrade, N.J.D., Ramos, A.M., Vanetti, M.C.D., Stringheta, P.C., Chaves, J.B.P. 2014. Decontamination by ultrasound application in fresh fruits and vegetables. Food Control, Vol. 45 (Supplement C), pp. 36-50. https://doi.org/10.1016/j.foodcont.2014.04.015

20. Smilanick, J.L. 2003. Washington Tree Fruit Postharvest Conference. December 2nd and 3rd Wenatchee, WA.

21. Soto-Silva, W.E., Nadal-Roig, E., González-Araya, M.C., Pla-Aragones, L.M. 2016. Operational research models applied to the fresh fruit supply chain. European Journal of Operational Research, Vol. 251, Iss. 2 pp. $345-355$. https://doi.org/10.1016/j.ejor.2015.08.046

22. Sowbhagya, H.B., Chitra, V.N. 2010. Enzyme-assisted extraction of flavorings and colorants from plant materials. Critical Reviews in Food Science and Nutrition, Vol. 50, Iss. 2, pp. 146-161. https://doi.org/10.1080/10408390802248775

23. Ssemanda, J.N., Reij, M., Bagabe, M.C., Muvunyi, C.M., Joosten, H., Zwietering, M.H. 2017. Indicator microorganisms in fresh vegetables from "farm to fork" in Rwanda. Food Control, Vol. 75 (Supplement C), pp. 126-133. https://doi.org/10.1016/j.foodcont.2016.12.031

24. Suslow, T.V. 2004. Ozone applications for postharvest disinfections of edible horticultural crops. University of California: Division of Agriculture and Natural Resources. Publication 8133, pp.8.

25. Tzortzakis, N., Chrysargyris, A. 2017. Postharvest ozone application for the preservation of fruits and vegetables. Food Reviews International, Vol. 33, Iss. 3, pp. 270-315. https://doi.org/10.1080/87559129.2016.1175015 